\title{
Knowledge, Attitudes, and Awareness Towards Newborn Screening in Association with Received Prenatal Care: A Survey of Primiparous Postpartum Mothers at the Philippine General Hospital
}

\author{
Bradley Ashley G. Ong, ${ }^{1}$ Lorena Margarita B. Osorio, ${ }^{1}$ Meleeze A. Ongtauco, ${ }^{1}$ Gabriel Paulo C. Orosco, RMT, ${ }^{1}$ \\ Dave Albert D. Patrimonio, ${ }^{1}$ Alista D. Perez, ${ }^{1}$ Switzale M. Pidlaoan, ${ }^{1}$ Er Joshua B. Pilotin, RMT, ${ }^{1}$ \\ Raphael Angelo E. Quevedo, ${ }^{1}$ Patricia Kate F. Regala ${ }^{1}$ and Jose M. Carnate, MD ${ }^{2}$ \\ ${ }^{1}$ College of Medicine, University of the Philippines Manila \\ ${ }^{2}$ Department of Pathology, College of Medicine, University of the Philippines Manila
}

\begin{abstract}
Background. Newborn screening (NBS) is a procedure for the immediate detection of genetic, metabolic, and endocrine disorders in neonates and is crucial for prompt treatment should such disorders be identified. In the Philippines, Republic Act 9288 requires health workers to properly inform mothers regarding NBS and its importance before the procedure.
\end{abstract}

Objective. To determine the knowledge, attitude, and awareness of primiparous postpartum mothers towards NBS Methods: A survey questionnaire was administered to primiparous mothers from Wards 15 and 16 of the Philippine General Hospital from April 11 through May 14, 2017. Results of primiparous postpartum mothers with or without previous prenatal check-ups were then compared.

Results. We surveyed 160 mothers, with half (56.3\%) aged between 20 and 29 years. There were 149 mothers with and 11 without prenatal checkups. Mothers with previous prenatal checkups were more likely to be aware of NBS than those without prenatal checkups. Knowledge on NBS of mothers with previous prenatal checkups was higher on average compared to those without previous prenatal checkups. There was no significant difference in attitude between mothers with or without prenatal checkups.

Conclusion. Prenatal checkups increased the awareness and knowledge of primiparous mothers' towards NBS, and thus can be a potent vehicle where healthcare providers may inform the mother on the process and purpose of this procedure.

Key Words: newborn screening, primiparous, knowledge, awareness, attitudes

\section{INTRODUCTION}

Corresponding author: Bradley Ashley G. Ong

College of Medicine

University of the Philippines Manila

547 Pedro Gil Street, Ermita, Manila 1000, Philippines

Email: bgong@up.edu.ph
Newborn screening (NBS) involves various biochemical tests performed during the first few hours or days of postnatal life. Its main goal is the early identification of genetic, metabolic or endocrine conditions in affected neonates. ${ }^{1}$ Early detection is crucial because prompt intervention can reduce mortality, morbidity, and associated disabilities that may otherwise develop later in life in undiagnosed and

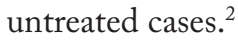

The biochemical tests are a key component of comprehensive NBS programs, which include education, screening, 
follow-up, diagnosis, treatment, management, and evaluation. ${ }^{3}$ The concept of NBS was first introduced in the Philippines in 1996 but it was only in 2004 that it was ratified as Republic Act 9288 and fully integrated into the public health system. The current Philippine NBS program dictates that the screening should be performed after 24 hours of life but not later than 3 days from the complete delivery of the newborn. The health practitioner has the responsibility to inform the parents or legal guardian of the newborn about the availability, nature, and benefits of newborn screening prior to delivery. ${ }^{4}$

It is still unknown whether the effects of government promotion strategies for NBS are palpable, and whether prenatal checkups have been used as avenues for disseminating information. The success of NBS programs depends largely on parental participation and approval. This study will assess the knowledge, attitude and awareness of the Filipino women towards the NBS program and its psychological impact, to evaluate the outcome of the NBS program. This study aimed to compare knowledge, attitudes, and awareness towards NBS between postpartum primiparous mothers with and without previous prenatal checkups in the Philippine General Hospital (PGH).

\section{MATERIALS AND METHODS}

We conducted a comparative cross-sectional study. One group was composed of mothers who have had previous prenatal checkups, while the control group was those without previous prenatal checkups.

Primiparous mothers who have recently given birth to term babies at the PGH were chosen through convenience sampling. We obtained informed consent after explaining to the participants the following information: purpose of the study, risks and inconveniences, possible benefits, provision for injury or related illness, contact person, voluntariness of participation and confidentiality. Sample size was based on the total number of respondents recruited for the survey for the duration of the sampling period.

The survey questionnaire was in Filipino and was adapted from existing validated instruments used in infant and NBS research. ${ }^{5-8}$ The questionnaire was modified accordingly to fit the topic and the Philippine setting. The original questionnaire was translated into Filipino using the forward-backward-forward method. The forward translation was done by an independent translator, who was proficient in both English and Filipino. The second translator, who was proficient in both languages, translated the questionnaire back into English. The translated and back-translated versions of the questionnaire were compared point by point by the investigators, who were all well-versed in both the English and Filipino language. The variations were resolved between the two versions and forward final translation was produced (Appendix Table A-1). Categorical divisions of the demographic parameters (age group, urban and rural residence, and educational profile) were based from those by the Philippine Statistics Authority. ${ }^{9-11}$

The 29-item questionnaire was composed of the following domains: (1) socio-demographic characteristics (age, educational attainment, location, and marital status); (2) awareness about existence of NBS; (3) knowledge about NBS as a medical procedure and as a public health program, and (4) attitude towards implications and use of test results. The translated survey was reviewed by members from Department of Obstetrics and Gynecology - Philippine General Hospital to ensure content validity. The questionnaire was administered to those who have consented. Responses were collected within the day.

Knowledge scores were computed and averaged based on two categories: NBS as a medical procedure and NBS as a public health program. Attitude scores, which were evaluated using the Likert scale, were computed and averaged based on two categories: towards implications of NBS results and towards use of results for research. Each of the five choices (strongly agree, somewhat agree, unsure, somewhat disagree, strongly disagree) were assigned a numerical value from 1 to 5. The closer the attitude score to 1 , the more positive the participant's opinion for that category. Refer to Appendix Table A-1 for the questions classified in each category and averaged.

Responses were analyzed using descriptive statistics. Means were tested for statistical difference using chi-squared test for independence for qualitative data and independent samples t-test for quantitative data. Power analysis was performed to evaluate whether values deemed not significant may be due to sample size. Statistical analyses were performed primarily using IBM SPSS Statistics for Windows, version 21.0, with $G^{*}$ Power 3.1 for power analyses. ${ }^{12,13}$

\section{RESULTS AND DISCUSSION}

\section{Demographic characteristics}

A total of 160 mothers were surveyed, from April 11 through May 14, 2017, via convenience sampling at Wards 15 and 16 of the PGH. There were 149 mothers with and 11 without prenatal checkups. Among those with prenatal checkups, majority $(138,92.6 \%)$ had more than one, with the remainder $(11,7.4 \%)$ only having one.

Majority of mothers were aged $20-29$ years old (56.3\%) followed by mothers $<20$ years old (35.6\%). According to the 2013 data from the Philippine Statistics Authority, majority of Filipino women who are pregnant with their first child are from ages $20-24(42.6 \%) .{ }^{14}$ (Table 1 )

Majority of the mothers had partners at the time of the survey (76.9\%) and were from urban communities (85\%). As a tertiary hospital, $\mathrm{PGH}$ is one of the referral centers of other primary and secondary hospitals as well as primary healthcare centers in Metro Manila. ${ }^{15}$

Majority of mothers finished secondary education $(53.8 \%)$, and $22.5 \%$ finished tertiary education. The data is 
Table 1. Demographic profile of respondents

\begin{tabular}{|c|c|c|c|c|c|c|}
\hline \multirow[t]{2}{*}{ Demographic Variable } & \multicolumn{2}{|c|}{ Total $(\mathrm{N}=160)$} & \multicolumn{2}{|c|}{$\begin{array}{l}\text { With prenatal } \\
\text { consult ( } \mathrm{n}=149 \text { ) }\end{array}$} & \multicolumn{2}{|c|}{$\begin{array}{c}\text { Without prenatal } \\
\text { consult }(n=11)\end{array}$} \\
\hline & $\mathbf{n}$ & $\%$ & $\mathbf{n}$ & $\%$ & $\mathbf{n}$ & $\%$ \\
\hline \multicolumn{7}{|l|}{ Maternal age } \\
\hline$<20$ & 57 & 35.6 & 50 & 87.7 & 7 & 12.3 \\
\hline $21-29$ & 90 & 56.3 & 87 & 96.7 & 3 & 3.3 \\
\hline $30-39$ & 12 & 7.5 & 11 & 91.7 & 1 & 8.3 \\
\hline \pm 40 & 1 & 0.6 & 1 & 100.0 & 0 & 0.0 \\
\hline \multicolumn{7}{|l|}{ Marital status } \\
\hline Partner/spouse & 123 & 76.9 & 116 & 94.3 & 7 & 5.7 \\
\hline No partner & 37 & 23.1 & 33 & 89.2 & 4 & 10.8 \\
\hline \multicolumn{7}{|l|}{ Type of settlement } \\
\hline Urban & 136 & 85.0 & 127 & 93.4 & 9 & 6.6 \\
\hline Rural & 24 & 15.0 & 22 & 91.7 & 2 & 8.3 \\
\hline \multicolumn{7}{|l|}{ Educational attainment } \\
\hline Below Grade 1/Informal & 2 & 1.3 & 1 & 50.0 & 1 & 50.0 \\
\hline Finished elementary school & 14 & 8.8 & 12 & 85.7 & 2 & 14.3 \\
\hline Finished high school & 86 & 53.8 & 81 & 94.2 & 5 & 5.8 \\
\hline Finished vocational school & 22 & 13.8 & 20 & 90.9 & 2 & 9.1 \\
\hline Finished tertiary or higher & 36 & 22.5 & 35 & 97.2 & 1 & 2.8 \\
\hline
\end{tabular}

similar to that from the Philippine Statistics Authority in 2013, where 44\% of Filipino women who were pregnant with their first child had elementary education while around $27 \%$ had high school education and $21 \%$ had college education.

Majority of the mothers with prenatal checkups (58\%, $\mathrm{n}=149$ ) were aged 20-29 while majority of those without prenatal checkups $(64 \%, n=11)$ were aged below 20 . This is consistent with the findings of the most recent Maternal and Child Health Survey conducted by the Philippine Statistics Authority in 2002, where it was observed that there were more mothers aged 15-19 who did not have any prenatal consults compared to those in other age groups. ${ }^{14}$

\section{Awareness of NBS}

Overall, majority of patients were aware of NBS (71\%). A similar study in Western Australia reported higher awareness among mothers (93\%), but the study included multigravid mothers in the sample. ${ }^{5}$

Mothers with prenatal checkups were significantly more aware of NBS $(111 / 149,74 \%)$ than those without (3/11, 27\%) $\left(\chi^{2}=0.001 ; \mathrm{P}=0.05\right)$ (Figure 1). Moreover, majority of those with prenatal checkups $(122 / 160,82 \%)$ perceived that these have contributed to their understanding of NBS.

Despite this, a quarter $(38 / 149,26 \%)$ of mothers with prenatal checkups were still not aware of the NBS process. There was $5 \%$ who did not perceive their prenatal checkups as a helpful source of NBS information. It has been shown that some prenatal care providers do not discuss newborn screening more because their patients do not ask them about it, or because they themselves do not have the necessary materials or knowledge to educate them. ${ }^{16}$ However, Philippine law obligates all health practitioners to inform parents or legal guardians of newborns about NBS.
Table 2. Awareness of respondents

\begin{tabular}{|c|c|c|}
\hline \multirow{2}{*}{ Variable } & \multicolumn{2}{|c|}{ Total $(\mathbf{N}=160)$} \\
\hline & n & $\%$ \\
\hline \multicolumn{3}{|l|}{ Awareness of NBS prior to survey } \\
\hline Aware & 114 & 71.3 \\
\hline Not aware & 46 & 28.8 \\
\hline \multicolumn{3}{|l|}{ Source of information $(n=114)$} \\
\hline Midwife & 15 & 13.2 \\
\hline Pamphlet or other reading material & 10 & 8.8 \\
\hline Physician & 52 & 45.6 \\
\hline Family or friends & 32 & 28.1 \\
\hline Internet & 5 & 4.4 \\
\hline \multicolumn{3}{|l|}{ Satisfaction with information provided ( $n=114)$} \\
\hline Satisfied & 30 & 26.3 \\
\hline Dissatisfied & 38 & 33.3 \\
\hline Unsure & 46 & 40.4 \\
\hline \multicolumn{3}{|l|}{$\begin{array}{l}\text { Perceived helpfulness of prenatal checkup as } \\
\text { source of NBS knowledge }(n=149)\end{array}$} \\
\hline Helped with understanding of NBS & 122 & 81.9 \\
\hline Not helped with understanding of NBS & 8 & 5.4 \\
\hline Unsure & 19 & 12.8 \\
\hline
\end{tabular}

The most common sources for NBS information were physicians (46\%), family or friends (28\%), and midwives (13\%). Satisfaction with knowledge on NBS was equally distributed, among the affirmative (26\%), negative (33\%), and unsure (40\%).

\section{Knowledge about NBS}

Mothers with prenatal checkup had significantly higher mean scores for knowledge on NBS as a medical procedure than those without $(t(158)=2.20, \mathrm{P}=0.03)$. As a public health program, however, there was no significant difference 


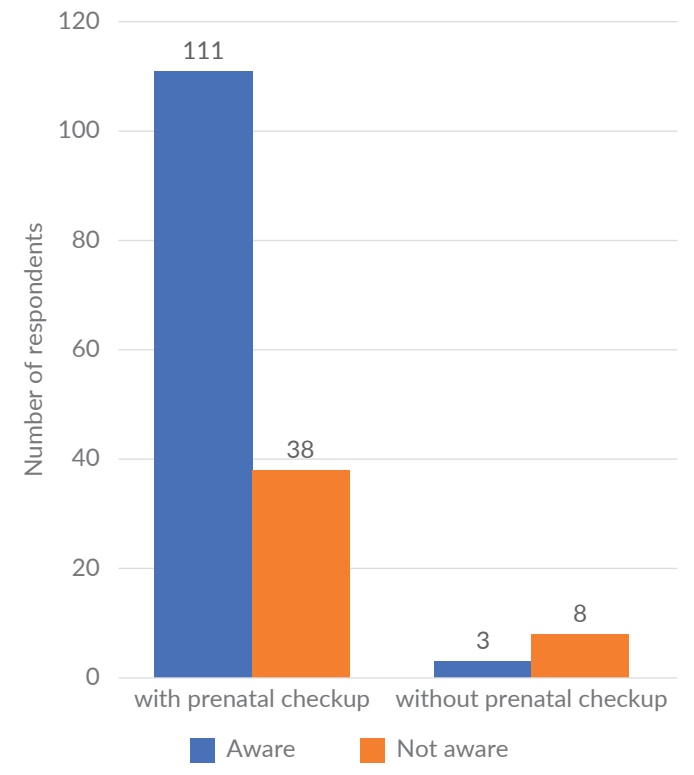

Figure 1. Distribution of mothers self-reporting as aware or not aware of NBS with and without previous prenatal checkups.

$(t(158)=1.20, \mathrm{P}=0.23)$. Similar findings from another study also showed that a mother who has had prenatal checkup is more likely to have a better grasp of the procedure and the benefits offered by NBS of the condition in comparison with an individual who has not. ${ }^{17}$

This indicates that prenatal checkups may be a critical determinant in the NBS knowledge attained by mothers. Therefore, it may be beneficial for health professionals to provide this information during the prenatal period. ${ }^{17}$. Moreover, facilitation and encouragement of prenatal checkups for pregnant women and women desirous of pregnancy may give more detail to be passed onto parents, and provide an opportunity for questions or clarifications.

The lack of significant difference in knowledge on NBS as a public health program suggests that current prenatal checkup services do not provide adequate information about health financing and policies on NBS. This is supported by a similar study which observed that the enhancement of primary care providers' educational role in the public health components of NBS may have beneficial results with the knowledge attained by mothers. ${ }^{18} \mathrm{~A}$ power analysis for NBS as a public health program (power $=0.27$ ) deemed that these results are more likely to be found only in this sample.

Mothers reported receiving information about NBS mainly through physicians (32.5\%), with only a small proportion of women reported reading the pamphlet (6.3\%). Therefore, other forms of communicating this information on NBS, such as through midwives, community health workers, and related organizations at the grassroots' level, must be explored. ${ }^{19}$

There is a difference between the respondent's level of knowledge and their educational attainment. Those finished

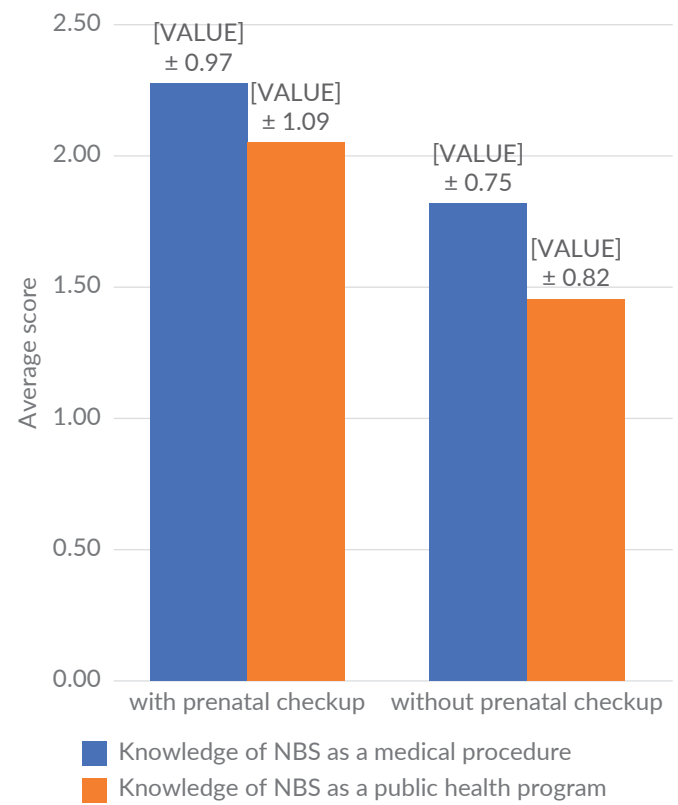

Figure 2. Average knowledge scores of mothers with and without prenatal checkup.

with tertiary education scored a 0.46 to 1 point higher average than those not finished with elementary education for both those with previous checkups and those without. This implies that the lower the respondent's educational attainment, the lower her level of knowledge. Indeed, educational attainment can greatly affect in making choices for the growth and development of their children. Greater education for mothers contributes to new skills, beliefs, and choices about sound health and nutritional practices that can directly influence child health. ${ }^{20}$

\section{Attitudes towards Implications of NBS Results}

Most respondents, regardless of prenatal checkup frequency, strongly agreed with the statements, with majority of mothers (88.8\%) strongly agreeing with the second question regarding the help of early diagnosis in preparation for the child's needs. This suggests that the mothers were confident that newborn screening will help them prevent or mitigate a disease. Similar results have been reported in the literature. ${ }^{6,21}$ Two-thirds (68.1\%) of respondents strongly agreed with the fourth question regarding change in feelings towards newborn if affected with a genetic disorder. However, 1 in 10 of new mothers were unsure, implying that the applicability of newborn screening for future pregnancies might not be clear to some mothers. It has been noted that a considerable proportion of new mothers did not find NBS useful in making future reproductive choices; however, the primary beneficiary of NBS is the newborn undergoing the procedure. ${ }^{19}$

Mean attitude toward newborn screening as a medical procedure is generally positive. There is no significant difference between the mean attitude score of those with 
Table 3. Percentage of responses to attitude questions on implications of results among mothers with or without previous prenatal checkups

\begin{tabular}{|c|c|c|c|c|}
\hline \multirow[t]{2}{*}{ Statements } & \multicolumn{2}{|c|}{$\begin{array}{l}\text { With prenatal } \\
\text { checkup }\end{array}$} & \multicolumn{2}{|c|}{$\begin{array}{l}\text { Without } \\
\text { prenatal } \\
\text { checkup }\end{array}$} \\
\hline & $\mathbf{n}$ & $\%$ & n & $\%$ \\
\hline \multicolumn{5}{|c|}{ Valuable for early detection of genetic disorder } \\
\hline Strongly agree & 129 & 86.58 & 8 & 72.73 \\
\hline Somewhat agree & 14 & 9.40 & 2 & 18.18 \\
\hline Unsure & 4 & 2.68 & 1 & 9.09 \\
\hline Somewhat disagree & 1 & 0.67 & 0 & 0.00 \\
\hline Strongly disagree & 1 & 0.67 & 0 & 0.00 \\
\hline \multicolumn{5}{|c|}{ Early detection will help in preparation } \\
\hline Strongly agree & 133 & 89.26 & 9 & 81.82 \\
\hline Somewhat agree & 10 & 6.71 & 0 & 0.00 \\
\hline Unsure & 5 & 3.36 & 2 & 18.18 \\
\hline Somewhat disagree & 0 & 0.00 & 0 & 0.00 \\
\hline Strongly disagree & 1 & 0.67 & 0 & 0.00 \\
\hline \multicolumn{5}{|l|}{ Anxiety with results of test } \\
\hline Strongly agree & 82 & 55.03 & 7 & 63.64 \\
\hline Somewhat agree & 28 & 18.79 & 2 & 18.18 \\
\hline Unsure & 20 & 13.42 & 1 & 9.09 \\
\hline Somewhat disagree & 9 & 6.04 & 0 & 0.00 \\
\hline Strongly disagree & 10 & 6.71 & 1 & 9.09 \\
\hline \multicolumn{5}{|c|}{ Feelings will not be affected if child is affected } \\
\hline Strongly agree & 116 & 77.85 & 9 & 81.82 \\
\hline Somewhat agree & 13 & 8.72 & 0 & 0.00 \\
\hline Unsure & 9 & 6.04 & 1 & 9.09 \\
\hline Somewhat disagree & 4 & 2.68 & 1 & 9.09 \\
\hline Strongly disagree & 7 & 4.70 & 0 & 0.00 \\
\hline \multicolumn{5}{|c|}{ Better to know early if child has genetic disorder } \\
\hline Strongly agree & 126 & 84.56 & 10 & 90.91 \\
\hline Somewhat agree & 16 & 10.74 & 0 & 0.00 \\
\hline Unsure & 4 & 2.68 & 1 & 9.09 \\
\hline Somewhat disagree & 0 & 0.00 & 0 & 0.00 \\
\hline Strongly disagree & 3 & 2.01 & 0 & 0.00 \\
\hline \multicolumn{5}{|c|}{ Information to be used in subsequent pregnancies } \\
\hline Strongly agree & 100 & 67.11 & 9 & 81.82 \\
\hline Somewhat agree & 18 & 12.08 & 1 & 9.09 \\
\hline Unsure & 15 & 10.07 & 1 & 9.09 \\
\hline Somewhat disagree & 6 & 4.03 & 0 & 0.00 \\
\hline Strongly disagree & 10 & 6.71 & 0 & 0.00 \\
\hline
\end{tabular}

prenatal checkup $(M=1.33, S D=0.53)$ and those without $(M=1.30, S D=0.64)(\mathrm{t}(158), \mathrm{P}=0.746)$. Power analysis (power $=0.07$ ) indicates that the sample size should be expanded in order to make an acceptable conclusion between the two groups. This confirms results of a previous study with a remarkably positive reception to NBS in Saudi Arabia. ${ }^{22}$

Apart from the statements in Appendix Table A-1, two additional statements were also rated by the respondents. The first was "Nag-aalala ako sa magiging resulta $n g$ test $n g$ aking sanggol." Only half of the respondents (55.6\%) strongly agreed with this statement. Majority (74.4\%) agreed in some way. $13.1 \%$ of the respondents said they are unsure; this suggests either a confidence in receiving desirable results or an indifference towards the results of the screening, both of which may explain their lack of worry. There was no significant difference of attitude score for those with prenatal checkup/s $(\mathrm{M}=1.91 \pm 1.24)$ and those without $(\mathrm{M}=1.73 \pm$ 1.27) (Independent two-tailed t-test, $\mathrm{t}(158)=0.46 ; \mathrm{P}=0.65$ ). Power analysis (power $=0.55$ ) indicates that these findings are more likely confined to this sample.

The second additional statement was "Hindi magbabago ang pagturing o pagtanaw ko sa aking sanggol sakaling mayroon siyang sakit na namamana." This garnered the strong support of $78.1 \%$ of respondents. These results suggest that majority will not change their attitude towards their firstborn based on the results. However, $13.8 \%$ had their reservations, with $4.4 \%$ of the respondents strongly disagreeing. This is reasonable; diagnosis of a birth defect and care for the affected child can take a devastating toll on the physical, mental, emotional, and financial health of the family, particularly the mother. Many parents facing this predicament experience depression, fear, anxiety, guilt, embarrassment, and shame. ${ }^{22}$ There was no significant difference of attitude score for those with prenatal checkup $(\mathrm{M}=1.4765 \pm 1.04999)$ and those without $(\mathrm{M}=1.4545 \pm 1.3573)$ (Independent two-tailed $\mathrm{t}$-test, $\mathrm{t}(158)=0.07 ; \mathrm{P}=0.947)$. Power analysis (power = 0.0818 ) indicates that a larger sample size is recommended for a firmer conclusion.

\section{Attitudes towards Use of NBS Test Results for Research}

There was no significant difference between the mean attitude score of those with $(M=1.82, S D=0.67)$ and without prenatal checkup $(M=2.00, S D=0.86)$ in their attitudes

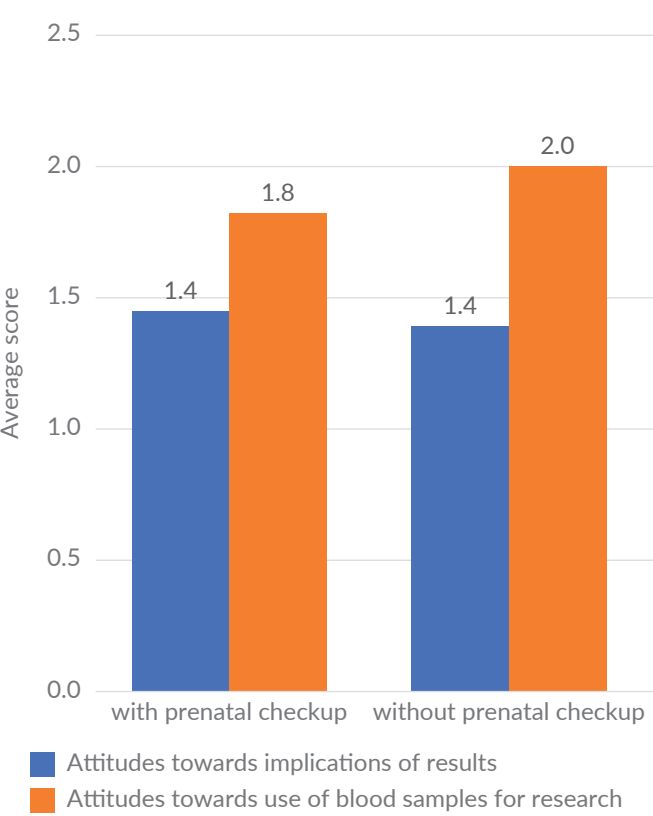

Figure 3. Average attitude scores of mothers with and without prenatal checkup. 
towards newborn screening as a tool for research $(t(158)$ $=-0.830, P=0.41)$. Power analysis $(\mathrm{P}=0.1801)$ shows low statistical power for this result. Nonetheless, the result indicates that there is lack of consent or information to the parents about the use of results as a source for research whether they had previous prenatal consults or not.

Recent lawsuits in Texas and Minnesota have reported the use of residual NBS for research unrelated to the initial screenings without parental consent. The necessity of parental consent may hinder research for the advancement and well-being of public health. ${ }^{23}$ New Zealand legal framework states that it is the decision of the parents whether the leftover blood spots are stored or returned after screening. ${ }^{24}$ Blood spot collections containing DNA can be a source of population-representative genetic samples that could be used for genomic studies. ${ }^{25}$ While some advocates emphasize the need for parental consent, others claim that it is not necessary provided that the samples were disidentified. Medical professionals suggest forming a protocol that protects families and researchers without imposing an undue burden. ${ }^{26}$

\section{Implications on actual practice}

The findings of the study suggest that there is greater awareness and knowledge on NBS among Filipino mothers who have had prenatal check-ups. The prenatal checkup therefore may be seen as a bridge where NBS may be introduced and concerns clarified between patient and physician.

It is widely accepted that parents are undereducated about newborn screening. ${ }^{26}$ The reason for this is that although testing is mandatory, education for this is not. Even if there are efforts to educate through brochures, pamphlets and programs, the responsibility for the act of educating parents is at risk of being diffused because these programs are run by state public health agencies but administered by health care providers in hospitals. Despite great progress since the introduction of NBS in the Philippines, implementation of NBS as a national tool requires better collaboration and education among clinicians, researchers, and patients to facilitate an evidence-based approach.

\section{CONCLUSION AND RECOMMENDATIONS}

Prenatal checkups may increase knowledge and awareness on newborn screening but does not appear to influence attitude. can be a potent vehicle where healthcare providers may inform the mother regarding the process and purpose of this lifesaving procedure. Better integration of government policy and information dissemination by healthcare providers should be made a priority for improved understanding of mothers towards NBS.

For future studies, it is recommended that a larger sample size be obtained, in light of the weak statistical power of the analyses. The survey may also be administered in different hospitals to see effect of location and type of hospital on results. PGH handles complicated cases; thus, mothers in PGH are more likely to consult for a prenatal checkup and in turn be better informed about NBS. Retention time of mothers on NBS knowledge may also be a factor in overall understanding, and can be evaluated as well.

\section{Acknowledgments}

The researchers wish to express their sincerest gratitude to the Department of Obstetrics and Gynecology, Dr. Renee Medalla, and Ms. Cuchon for their assistance.

\section{Statement of Authorship}

All authors participated in data collection and analysis, and approved the final version submitted.

\section{Author Disclosure}

All authors declared no conflicts of interest.

\section{Funding Source}

The author(s) received no financial support for the research, authorship, and/or publication of this article.

\section{REFERENCES}

1. Therrell BL, Padilla CD, Loeber JG, Kneisser I, Saadallah A, Borrajo GJ, et al. Current status of newborn screening worldwide: 2015. Semin Perinatol. 2015 Apr; 39(3):171-87.

2. Padilla CD, Aguirre TB. Enhancing case detection of selected inherited disorders through expanded newborn screening in the Philippines. Acta Med Philipp. 2012; 46(4):24-9.

3. Klein J. Newborn screening from an international perspectivedifferent countries, different approaches. Clin Biochem. 2011 May; 44(7):471-2.

4. Padilla CD. Newborn screening in the Philippines. Southeast Asian J Trop Med Public Health. 2003; 34 Suppl 3:87-8.

5. Davey A, French D, Dawkins H, O'Leary P. New mothers' awareness of newborn screening, and their attitudes to the retention and use of screening samples for research purposes. Life Sci Soc Policy. 2005 Dec;1:41.

6. Christie L, Wotton T, Bennetts B, Wiley V, Wilcken B, Rogers C, et al. Maternal attitudes to newborn screening for fragile $\mathrm{X}$ syndrome. Am J Med Genet A. 2013 Feb; 161A(2):301-11.

7. Twfeeq WF, Abed LM. Knowledge and attitudes of mothers toward newborn screening test in Baghdad city. Glob J Biosci Biotechnol. 2016; 5(2):171-6.

8. Newcomb P, True B, Walsh J, Dyson M, Lockwood S, Douglas B. Maternal attitudes and knowledge about newborn screening. MCN Am J Matern Child Nurs. 2013 Sep-Oct; 38(5):289-94; quiz 295-6.

9. Philippine Statistics Authority [Internet]. [Manila:] The Authority; [cited 2017 Mar 28]. Press release: New definition of urban areas adopted for statistical operations; 2004 Jan 30 [cited 2017 Mar 28]. Available from: http://nap.psa.gov.ph/pressreleases/2004/30Jan04_urban.asp

10. Philippine Statistics Authority [Internet]. [Manila]: The Authority; [cited 2017 Mar 28]. The educational attainment of the household population (results from the 2010 census); 2013 Jan 10 [cited 2017 Mar 28]. Available from: https://psa.gov.ph/content/educationalattainment-household-population-results-2010-census

11. Philippine Statistics Authority [Internet]. [Manila]: The Authority; [cited 2017 Mar 28]. Live births by age group of mother and by first birth order; 2010 Mar 8 [cited 2017 Mar 28]. Available from: https://psa.gov.ph/content/live-births-age-group-mother-and-firstbirth-order 
12. IBM Corp. IBM SPSS Statistics for Windows. Version 21.0[software]. 2012 [cited 2017 May 14]. Available from: https://www.ibm.com/ support/knowledgecenter/SSLVMB_21.0.0

13. Faul F, Erdfelder E, Buchner A, Lang AG. Statistical power analyses using $G^{*}$ Power 3.1: tests for correlation and regression analyses. Behav Res Methods. 2009 Nov; 41(4):1149-60.

14. Philippine National Statistics Office. 2002 maternal and child health survey [Internet]. Manila: The Office; 2003 March [cited 2017 May 16]. Available from: https://psa.gov.ph/sites/default/files/2002\%20 MCHS.pdf

15. Philippine General Hospital [Internet]. [Manila]: The Hospital; c2017. About us; [cited 2017 May 16]. Available from: http://www.pgh.gov. $\mathrm{ph} / \mathrm{en} /$ about-us-1/

16. Faulkner LA, Feuchtbaum LB, Graham S, Bolstad JP, Cunningham GC. The newborn screening educational gap: what prenatal care providers do compared with what is expected. Am J Obstet Gynecol. 2006 Jan;194(1):131-7.

17. Lewis SM, Cullinane FM, Carlin JB, Halliday JL. Women's and health professionals' preferences for prenatal testing for Down syndrome in Australia. Aust N Z J Obstet Gynaecol. 2006 Jun; 46(3):205-11.

18. Andermann A, Blancquaert I, Beauchamp S, Costea I. Guiding policy decisions for genetic screening: Developing a systematic and transparent approach. Public Health Genom. 2011;14:9-16.

19. Padilla, CD. The HUGO Pan-Asian SNP Consortium: mapping human genetic diversity in Asia. Science. 2009; 326(1).
20. Miller JE, Rodgers YV. Mother's education and children's nutritional status: new evidence from Cambodia. Asian Dev Rev. 2009; 26(1): 131-65.

21. Quinlivan JA, Suriadi C. Attitudes of new mothers towards genetics and newborn screening. J Psychosom Obstet Gynaecol. 2006 Mar; 27(1):67-72.

22. Al-Sulaiman A, Kondkar AA, Saeedi MY, Saadallah A, Al-Odaib A, Abu-Amero KK. Assessment of the knowledge and attitudes of Saudi mothers towards newborn screening. Biomed Res Int. 2015; 2015:718674.

23. Whelan A. Federal newborn screening law emphasizes informed consent. 2015 Jan 16 [cited 2017 May 16]. In: Petrie-Flom Center and friends. Bill of Health: Examining the intersection of law and health care, biotech \& bioethics [Internet]. [Cambridge (MA)]: Harvard Law School, Petrie-Flom Center. [2012 Sep]-. [about 3 screens]. Available from: http://blogs.harvard.edu/billofhealth/2015/01/16/ federal-newborn-screening-law-emphasizes-informed-consent/

24. Privacy Act 1993 [Internet]. Newborn metabolic screening programme heel prick test; [cited 2017 May 16]. Available from: http://www. nsu.govt.nz/pregnancy-newborn-screening

25. Tarini BA, Goldenberg AJ. Ethical issues with newborn screening in the genomics era. Annu Rev Genomics Hum Genet. 2012; 13:381-93.

26. Pelias MK, Markward NJ. Newborn screening, informed consent, and future use of archived tissue samples. Genet Test. 2001 Fall; 5(3): $179-85$.

\section{APPENDIX}

Table A-1. Questions classified in categories for analysis

\section{Category Subcategory Items}

Knowledge NBS as a $\quad$ 1. Pwedeng mamatay ang isang sanggol o magkaroon ng sakit sa pag-iisip kung hindi siya isasailalim sa NBS. medical 2. Maraming dugo mula sa sanggol ang kailangan para sa NBS.

procedure $\quad 3$. Kailangang ulitin ang NBS kung ang sampol ng dugo ay kinuha paglampas ng 24 oras mula pagkapanganak.

4. Kung positibo ang resulta ng NBS, marapat na agad ipakonsulta sa duktor ang sanggol.

NBS as a $\quad$ 1. Sa ospital lamang pwedeng ipa-NBS ang sanggol.

public health 2. Ayon sa batas, kailangan ipaalam sa mga magulang ang newborn screening test bago manganak ang nanay.

program 3. Hindi kasama ang NBS sa Newborn Care Package (insurance) ng PhilHealth.

4. Ang dugong nakuha mula sa sanggol ay puwedeng gamitin sa mga pag-aaral para sa ikabubuti ng marami.

Attitudes Towards 1. Naniniwala akong sa tulong ng newborn screening ay maagang matutuklasan ang anumang namamanang sakit implications sa mga sanggol.

of results $\quad$ 2. Naniniwala akong mas maganda kung maaga kong malalaman ang kondisyon ng sanggol upang ito'y aking mapaghandaan.

3. Nag-aalala ako sa magiging resulta ng test ng aking sanggol.

4. Hindi magbabago ang pagturing o pagtanaw ko sa aking sanggol sakaling mayroon siyang sakit na namamana.

5. Mas panatag ako na matuklasan nang maaga kung mayroong sakit na namamana ang aking sanggol, kaysa hintayin pang lumitaw ang mga sintomas ng ganitong klaseng sakit habang siya ay lumalaki.

6. Gagamitin ko ang resulta ng test para sa mga susunod kong pagbubuntis.

Towards 1. Dapat ipagamit sa mga mananaliksik ang mga sampol ng dugo na ginagamit sa NBS.

use of test 2. Payag ako na ipagamit ang genetic na impormasyon ng aking sanggol sa mga pag-aaral.

results for 3. Ikagagalak kong makatulong sa mga pag-aaral, sa pamamagitan ng genetic na impormasyon ng aking anak.

research 4. Papayag lang ako na gamitin ang genetic test result ng aking anak kung ito ay para sa:

- Pag-intindi sa sakit na laganap sa aming komunidad

- Pagbuti ng pagsusuri para sa mga sakit ng bata

- Pag-unawa ang epekto ng paraan ng pamumuhay sa mga namamanang sakit
Awareness Existence
of NBS and
1. May kamalayan ka ba sa Newborn Screening (NBS) Program?
- Saan o kanino mo nalaman ang Newborn Screening Program?
frequency
of prenatal
2. Sa iyong palagay, sapat na ba ang iyong kaalaman tungkol sa Newborn Screening Program?
check up
3. Kumonsulta ka na ba sa isang doktor o health center mula noong ikaw ay magbuntis?
- Ilang beses ka na kumonsulta?
4. Nakatulong ba sa iyo ang mga check-up para pagtibayin ang iyong kaalaman patungkol sa Newborn Screening? 